\title{
Pelatihan dan Pendampingan Pengelolaan Sampah Organik Menjadi Kompos Dengan Metode Takakura di Desa Waduwani
}

\author{
Ika irawati ${ }^{1 *}$, Sri Yanti ${ }^{2}$, Nur Fitrianingsih ${ }^{3}$, Ihsan $^{4}$, Deddy Meirawan ${ }^{4}$ \\ ${ }^{I}$ Departement of Technology and Information Education, STKIP Taman Siswa, Bima, Indonesia. \\ ${ }^{2}$ Departement of Technology and Information Education, STKIP Taman Siswa, Bima, Indonesia. \\ ${ }^{3}$ Departement of Technology and Information Education, STKIP Taman Siswa, Bima, Indonesia. \\ ${ }^{4}$ Departement of Research and Evaluation, Muhammadiyah Prof. Dr. Hamka Postgraduate University, \\ Jakarta, Indonesia
}

\author{
Article history \\ Received: 19-10-2021 \\ Revised: 05-11-2021 \\ Accepted: 07-11-2021 \\ *Corresponding Author: \\ Ika irawati, \\ Departement of Technology \\ and Information Education, \\ STKIP Taman Siswa, Bima, \\ Indonesia;
}

Email: ika.irawati1989@gmail.com
Abstract: Garbage have been become big problem for our environment, especially the garbage at Waste Processing Site (TPA) on Waduwani Village. Several efforts have been made by government to reduce garbage volume. But these efforts have not been fully realized in the community. So that it is urgently needed an appropriate and comprehensive solution to reduce the volume of the garbage and its negative effect on environment. Training and assistance to make organic garbage to be the compost by using "Takakura method" is the one solution to reduce garbage problems. This activity is a Community Service for the community, especially women in Waduwani village, Woha sub-district of Bima, NTB. The objectives of this community service activity includes (1) Counseling the community to improve community knowledge and skills to make organic garbage properly and sustainably. (2) The management and training can reduce the volume of organic garbage generated from the house. (3) The results of training of compost made can be utilized by the community, especially to fertilize their plants. The method of implementing this activity is carried out in four stages, namely; socialization, Implementation program, Garbage processing, and finally Program evaluation. The results of Takakura Method are (1) IncreaseMothers knowledge and skills to manage the garbage (2) Reduce the garbage volume which generated at household/kitchen. (3) The results of make Takakura compost can be used directly by mothers to fertilize their plants.

Keywords: garbage management; takakura method

Abtrak: Sampah masih menjadi masalah yang besar bagi lingkungan dan masyarakat, khususnya sampah di Tempat Pemrosesan Sampah (TPA) Desa Waduwani. Beberapa upaya telah diupayakan oleh pemerintah untuk mengurangi volume sampah. Tapi upaya tersebut belum sepenuhnya terealisasi dengan baik di masyarakat. Sehingga sangat dibutuhkan solusi yang tepat dan komprenhensif untuk mengurangi volume sampah dan dampak buruknya bagi lingkungan. Salah satu solusi dari permasalahan sampah yaitu dengan Pelatihan dan Pendampingan Pengelolaan Sampah Organik menjadi Kompos dengan Metode Takakura di Desa Waduwani. Kegiatan ini merupakan Pengabdian Masyarakat bagi masyarakat khususnya ibu-ibu di desa Waduwani, kecamatan Woha, Kabupaten Bima, NTB. Tujuan kegiatan pengabdian kepada mesyarakat ini antara lain (1) Penyuluhan pada masyarakat untuk meningkatkan pengetahuan dan keterampilan masyarakat dalam mengelola sampah organic secara baik dan berkelanjutan. (2) Pengelolaan dan pelatihan ini dapat mengurangi volume sampah organik yang dihasilkan dari rumah/dapur. (3) Hasil pelatihan dan pengelolaan sampah yang berbentuk kompos dapat dimanfaatkan oleh masyarakat khususnya ibu untuk menyuburkan tanaman 
sayur maupun bunga. Metode pelaksanaan kegiatan pengabdian ini dilakukan dengan empat (4) tahapan yaitu; sosialisasi, pelaksanaan program, Kegiatan Pelaksanaan pengolahan Sampah, dan terakhir evaluasi Program. Hasil kegiatan pengabdian masyarakat melalui pelatihan dan pengelolaan sampah organic dengan metode Takakura yaitu (1) Adanya peningkatan pengetahuan dan keterampilan ibu-ibu dalam mengelola sampah (2) adanya pengengurangan volume sampah yang dihasilkan pada skala Rumah tangga/sampah dapur. (3) Hasil pelatihan berupa kompos dimanfaatkan langsung oleh ibu-ibu untuk menyuburkan tanaman bunga dan sayur.

Kata Kunci: : pengelolaan sampah; metode takakura

\section{PENDAHULUAN}

Sampah menjadi masalah besar dampaknya bagi masyarakat, lingkungan dan kesehatan. Setiap tahun volume sampah semakin meningkat, sehingga masalah sampah sudah menjadi masalah Negara bahkan dunia saat ini. Sehingga partisipasi semua pihak sangat dibutuhkan dalam mengurangi volume dan dampak negatif sampah.

Salah satu desa yang merasakan dampak negative dari sampah adalah desa Waduwani. Sejak tahun 2016 desa Waduwani, tepatnya di dareah persawahan dibangun Tempat Pemrosesan Sampah (TPA). TPA ini berjarak $2 \mathrm{Km}$ dari pemukiman Warga. Semua sampah yang diangkut dari berbagai Tempat penampungan sementara (TPS) se-Kecamatan Woha dibuang di Tempat Pemrosesan Sampah ini. TPA ini berlokasi di dekat persawahan milik Warga. Berdasarkan hasil wawancara dengan bapak (Ilyas, 2021) yang merupakan salah satu staf Desa Waduwani, beliau menjelaskan pada tahun 2010 TPA ini diresmikan oleh pemerintah daerah dan didirikan Instalasi Pengolahan Lumpur Tinja (IPLT). IPLT sempat beberapa beroperasi, tetapi Pengolahan lumpur Tinja ini mendapat kritikan dari masyarakat karena Limbah hasil pengolahan lumpur tinja ini menimbulkan bau dan mencemari lingkungan. (Arsip Desa, 2021) Sehingga di TPA ini hanya menjadi tempat pembuangan dan pengumpulan sampah saja. Volume sampah yang berada di TPA ini terus bertambah karena tidak adanya proses pengolahan sampah. Tim pengusul melakukan observasi pada keadaan IPLT ini belum beroperasi lagi. Keadaan lain pemrosesan samspah ini yaitu belum dibuatkan Tanggul, sehingga apabila datang musim Hujan, air yang bercampur hujan air sampah meluap dan merembes di persawahan warga dan sungai.

Seiring dengan bertambahnya jumlah penduduk dikecamatan Woha, khususnya desa Waduwani dan sekitarnya, bertambah juga volume sampah yang bertumpuk di TPA waduwani. Hasil wawancara dengan Pak (Rahmansyah, 2021) yang merupakan salah satu warga setempat menyatakan bahwa Sampah yang bertumpuk tersebut belum ada pengelolahan dan pemanfaatan sampah menjadi produk yang berguna. Yang masih ada yaitu beberapa pemulung yang mengambil sampah plastik dan sampah kardus untuk mereka jual. Sedangkan yang banyak tersisa adalah sampah organik, seperti sampah daun kering, sampah dapur dan sampah daun sayuran. Apabila datang musih hujan seperti saat ini, sampah organik tersebut menimbulkan bau yang cukup menyengat bagi para petani yang pergi ke sawah. Para petani terlebih tidak nyaman ketika air sampah yang kotor dan berbau merembes masuk di area persawahan. Berdasarkan Data yang tim peneliti himpun dari observasi lapangan, wawancara dari pihak warga dan pemerintah desa Waduwani terkait Tempat Pemroresan Sampah. Adapun masalah utama yang perlu mendapat perhatian khusus yaitu dampak negatif sampah organik bagi lingkungan di sekitar TPA Waduwani. Menurut Angelina dalam (Imelda, dkk, 2020, p. 107) menjelaskan jika sampah rumah tangga/organik merupakan salah satu sumber sampah yang cukup besar kontribusinya dalam pencemaran lingkungan. Penumpukan sampah organik dapat menimbulkan pencemaran tanah dan air, menimbulkan bau tidak sedap. Selain itu menjadi sarang binatang ataupun hewan, terutama nyamuk dan lalat yang dapat menjadi sumber penyakit. 
Namun keberadaan sampah organik dapat dikurangi dan diminimalisir. Salah satu cara untuk mengurangi jumlah sampah organik yaitu dengan mengolah sampah menjadi barang yang berguna dan dapat bermanfaat bagi masyarakat setempat. Sehingga Tim Peneliti merasa perlu diadakan pengabdian Masyarkat dengan Judul "Pelatihan dan Pendampingan Pengelolaan Sampah Organik menjadi Kompos dengan Metode Takakura di Desa Waduwani”. Dengan adanya Pelatihan dan Pendampingan sampah organic ini diharapkan dapat meminimalisir jumlah dan dampak sampah bagi lingkungan. Sampah organik yang akan diolah menjadi kompos dapat memberikan manfaat bagi masyarakat yaitu dapat meyuburkan tanaman dan bahkan dapat dijual dan dapat meningkatkan pendapatan masyarakat, khususnya ibu-ibu rumah Tangga. Alasan Tim pengabdian memilih Metode Takakura dalam pengolahan sampah yaitu metode ini sangat ramah lingkungan dan tidak menimbulkan bau. Selain itu, pengolahan dengan metode Takakura tidak membutuhkan halaman yang luas untuk mengolahnya. Menurut (Anonim, 2020) Metode ini cukup efektif dalam mengurangi sampah organik, terbukti dalam rentang waktu (2004-2009), metode ini berhasil menurunkan jumlah volume sampah yang dibuang di tempat Pembuangan Akhir (TPA) Benowo. Kegiatan pengabdian masyarakat yang dilakukan oleh dewi Jumriati, dkk (2020) yang berjudul "Penerapan teknologi kompos takakura bagi masyarakat Desa tanjung terdana kecamatan pondok kubang Bengkulu tengah sebagai upaya pemberdayaan Masyarakat sadar lingkungan. Dimana di desa tersebut masyarakat belum mengetahui bahan bahan organic untuk menjadi bahan untuk fermentasi pembuatan sampah. Masyarakat belum mengetahui keterampilan teknologi kompos dengan metode Takakura. Hasil pengabdian ini menunjukkan kegiatan ini telah meningkatkan pengetahuan dan keterampilan masyarakat Desa Tanjung Perdana dalam pengelolaan sampah rumah tangga menggunakan teknologi sederhana pembuatan kompos Takakura.

Tujuan kegiatan pengabdian kepada masyarakat ini antara lain (1) Penyuluhan pada masyarakat untuk meningkatkan pengetahuan dan keterampilan masyarakat dalam mengelola sampah organic secara baik dan berkelanjutan. (2) Pengelolaan dan pelatihan ini dapat mengurangi volume sampah organik yang dihasilkan dari rumah/dapur. (3) Hasil pelatihan dan pengelolaan sampah yang berbentuk kompos dapat dimanfaatkan oleh masyarakat khususnya ibu untuk menyuburkan tanaman sayur maupun bunga.

\section{METODE}

Metode pelaksanaan pengabdian kepada masyarakat ini dilakukan dengan empat (4) tahapan, dan kegiatan awal sampai akhir yaitu evaluasi selama kurang lebih 3 minggu. Adapun tahapannya yaitu;

1. Sosialisasi

kegiatan ini merupakan langkah sosialisasi program Kegiatan pengabdian kepada Mitra, Pemerintah

Desa dan masyarakat. Kemudian tim pengabdian melakukan rapat terkait waktu dan tempat pelaksanaan tugas, kemudian penyusunan undangan. Setelah itu baru dilakukan pembagian undangan

2. Pelaksanaan Program,

Pembuatan kompos ini akan dibagi dalam beberapa kelompok. Ibu-ibu dari desa waduwani berjumlah 15 orang, akan dibagi menjadi 5 kelompok, setiap kelompok terdiri dari 5 orang. Sedangkan Desa Keli yaitu 1 kelompok, dan desa Naru 1 kelompok. Media utama yang di gunakan dalam mengolah sampah organik dengan metode Takakura adalah keranjang plastik yang berukuran $40 \mathrm{~cm} \times 25 \mathrm{~cm} \times 70 \mathrm{~cm}$. sampah organik yang dapat dihasilkan adalah $1,5 \mathrm{Kg}$. Tahap pertama yaitu dengan menyiapkan semua bahan dan peralatan yang dibutuhkan. Minggu pertama diundang 5 kelompok ibu-ibu dari 3 desa yaitu desa waduwani, desa keli dan desa Naru. Selain itu, Tim 
pengabdian juag mengundang kepala desa atau staf yang mewakili, dan beberapa masyarakat, jumlah menghindari kerumaunanan dan tetap mengikuti protocol kesahatan.

3. Kegiatan Pelaksanaan pengolahan Sampah,

Adapun langkah-langkah kegiatan adalah:

a) Penyampaian dan penjelasan materi tentang sampah dan metode Takakura oleh Narasumber

b) Ilustrasi pengelolaan sampah oleh Tim pengabdian dan narasumber

c) Penyampain sesi tanya jawab

Setelah penyampaian materi dan ilustrasi di minggu pertama, Tim pengabdian dan narasumber melakuan kegiatan lanjutan yaitu pengelolaan sampah organik menjadi pupuk kompos. Ibu-ibu dibagi menjadi 3 kelompok, kemudian langsung mempraktekkan pembuatan kompos dengan sampah organik, dengan tahapan sesuai dengan ilustrasi pemateri dan Tim pengabdian.

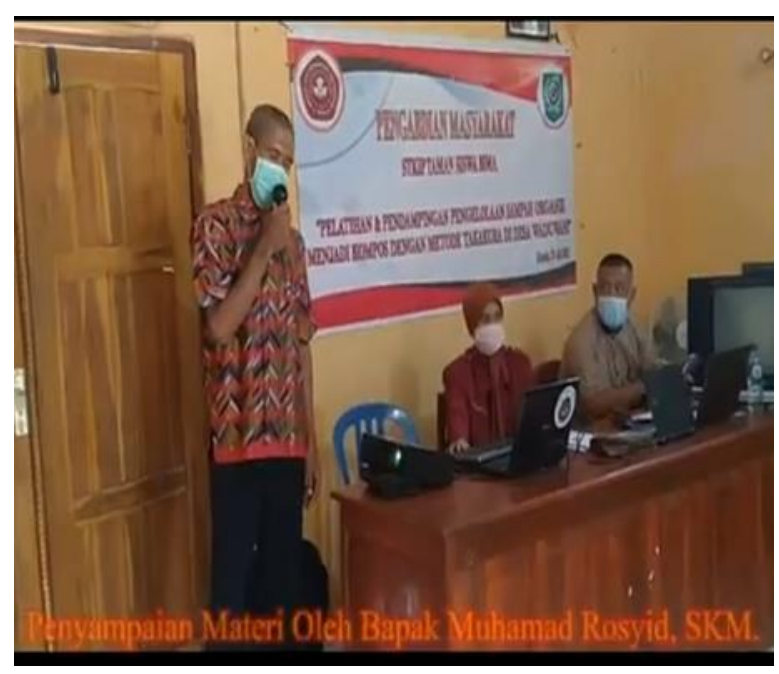

Gambar 1. Penyampaian materi

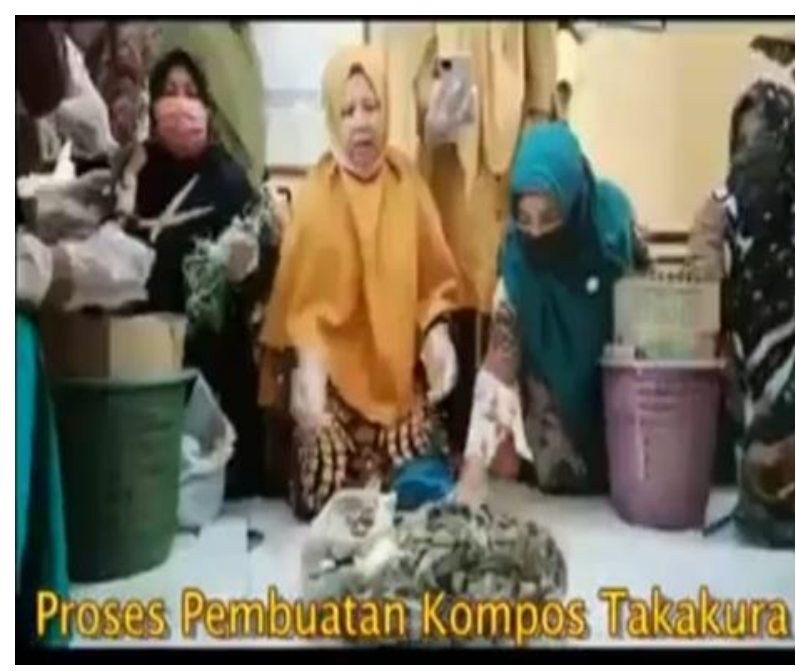

Gambar 2. Proses pembuatan kompos

\section{Evaluasi program.}

Kegiatan ini dilaksanakan di Aula Desa kantor desa Waduwani pada tanggal 31 Juli 2021. Evaluasi dilaksanakan untuk melihat keberhasilan kegiatan dalam kegiatan pengabdian kepada masyarakat telah dibuat pada saat kegiatan. Kompos organik yang telah didiamkan selama 10 hari. Setelah 10 hari kompos takakura dapat digunakan untuk menyuburkan tanaman sayur dan bunga. Evaluasi ditargetkan dan telah dilakukan sebanyak 2 kali. Evaluasi 1 yaitu melihat hasil kompos dan membagikan kepada masyarakat spya ibu-ibu bias memanfaatkan untuk kesuburan tanaman. Sedangkan evaluasi ke 2, untuk melihat efek pemakaian dan menanyakan apakah telah dipraktekkan pembuatan sampah dengan metode Takakura yang dilakukan oleh ibu-ibu PKK di rumah masing-masing. Sehingga kegiatan Pengabdian ini dilakukan selama kurang lebih 3 minggu.

\section{HASIL DAN PEMBAHASAN}

Pengelolaan sampah organik ini menggunakan keranjang Takakura yang memiliki prinsip kerja pengomposan aerob dengan melibatkan aktivitas mikroorganisme decomposer. Keranjang berlubang dilapisi dengan kardus dan ditutupi dengan bantalan sekam. Sehingga keranjang dijaga kelmbapannya. Beberapa faktor yang mempengaruhi proses pengomposan yaitu ukuran partikel, aerasi, rasio C:N, porositas, kelembaban, temperatur, pH, kandungan Murbandono dalam ( dewi, dkk 2020). 


\section{a) Tahapan Persiapan}

Tahapan persiapan dilakukan dengan menyiapkan bahan- bahan dan alat untuk pembuatan kompos. Alat utama yaitu keranjang berlubang, kardus bekas, bantal sekam, kain penutup (kain berongga) dan terakhir penutup keranjang. Aktivator pengurai organisme yang dipakai yaitu dengan menggunakan EM4. Sampah organik ini digabung denga sekam padi dan kompos.

Cara pembuatan kompos organic dengan metode Takakura yaitu dengan menyiapkan keranjang yang sudah dilapisi dengan kardus. Bagian bawah keranjang dialaskan dengan bantal sekam. Sedangkan sampah organik dicampur dengan sekam padi dan kompos. Kemudian tambahkan EM4. Setelah semuanya diaduk dan tercampur rata, tutup lagi dengan bantal sekam, setelah itu kain berongga dan terakhir ditutup dengan penutup keranjang.

\section{b) Penyampaian Materi}

Kegiatan pelatihan dan pengelolaan sampah organic menjadi kompos ini telah dilaksanakan di Aula kantor desa Waduwani pada tanggal 31 Juli 2021. Peserta pelatihan ini adalah ibu-ibu PKK perwakilan dari 3 desa yaitu dewa Waduwani sebagai tuan Rumah, Desa keli dan desa Naru. Jumlah peserta yang hadir yaitu 15 orang. Pemari dalam kegiatan ini yaitu terdiri dari 2 orang. Pemateri I menyampaiakan materi sampah dan dampaknya bagi kesehatan dan lingkungan. Adapaun materinya antara lain; pengertian dan jenis-jenis sampah, kebiasaan umum masyarakat terhapap pembungan sampah, dampak negative sampah organic bagi kesehatan dan lingkungan, dan manfaat pemanfaatan sampah. Sedangkan Pemateri II menyampaikan materi tentang; Definisi metode takakura, manfaat metode Takakura, alat dan bahan, serta cara pembuatan kompos dari sampah organic. Pemaparan materi dilakukan melalui media LCD Proyektor, dan disertakan dengan gambar yang relevan, agar mempermudah pemahaman para peserta.

Setelah penyampaian materi I dan II, dibuka sesi tanya jawab, peserta diberikan kesempatan memberikan 5 pertanyaan. Dan ada 5 peserta antusias bertanya kepada pemateri I dan II. Peserta sangat terinspirasi dengan pembuatan kompos dengan metode takakura ini, pasalnya peserta baru mengetahui dengan metode ini, ibu-ibu bisa mengolah sampah organic/sampah dapur dengan peralatan yang sederhana, praktis dan tidak menimbulkan bau (ramah lingkungan). Sampah dapur yang sebelumnya terbungang percuma, sekarang dapat dimanfaatkan menjadi kompos sangat berguna bagi kesuburan tanaman sayuran dan bunga milik masyarakat itu sendiri. Bahkan jika ibu-ibu bisa focus, produk kompos yang sudah diolah dapat bernilai jual untuk penghasilan tambahan ibu-ibu PKK sebagai mitra dalam kegiatan pengabdian ini.

\section{c) Pelaksanaan Pembuatan Kompos Takakura}

Pada tahap ini peserta ibu ibu PKK langsung mempraktekkan pembuatan kompos organic dengan metode takakura. Kegiatan diawali dngan pemotongan sampah organic menjadi potongan kecil sehingga lebih mempercepat proses pembusukan. Seperti yang pendapat Setyorini et al. dalam ( dewi, dkk 2020). bahwa sampai batas tertentu, semakin kecil ukuran potongan sayuran/sampah organik, semakin cepat pula waktu pembusukannya. Sampah organic yang dibawa oleh peserta seperti sisa sayuran, daun kering dan lain lain. Setelah menjadi potongan kecil kemudian dicampur dengan sisa nasi dan sisa makanan dari dapur. Setelah itu, dicampurkan dengan kompos dan sekam padi secukupnya, kemudian aduk/campur sampai merata. Kemudian tambahkan 3-4 takar EM4, takaran langsung menggunakan tutupan botol EM4.

Peserta dengan antusias melaksanakan kegiatan pembuatan kompos. Peserta dibagi menjadi 3 kelompok, setiap kelompok bekerja sama dengan baik. Tidak Nampak kesulitan yang berarti dari peserta. Karena pada saat penyampaian materi, peserta mendengarkan dengan saksama. Selain itu, peserta aktif bertanya pada saat sesi Tanya jawab terkait pembuatan kompos dengan metode Takakura 
Setelah sampah oeganik/komposter sudah siap, kemudian dimasukkan dalam keranjang. Keranjang yang sudah dilapisi dengan kardus bekas. Bagian alas diletakkan batal sekam, yang berfungsi sebagai penyerap air, dan sebagai kelambapan. Kemudian masukkan sampah organic yg sudah tercampur. Kemudian tutup lagi dengan bantalan sekam. Setalah itu tutup dengan kain berpori (kain berwarna gelap), terakhir ditutup dengan tutup keranjang (bisa juga menggunakan kardus sebagai penutupnya.

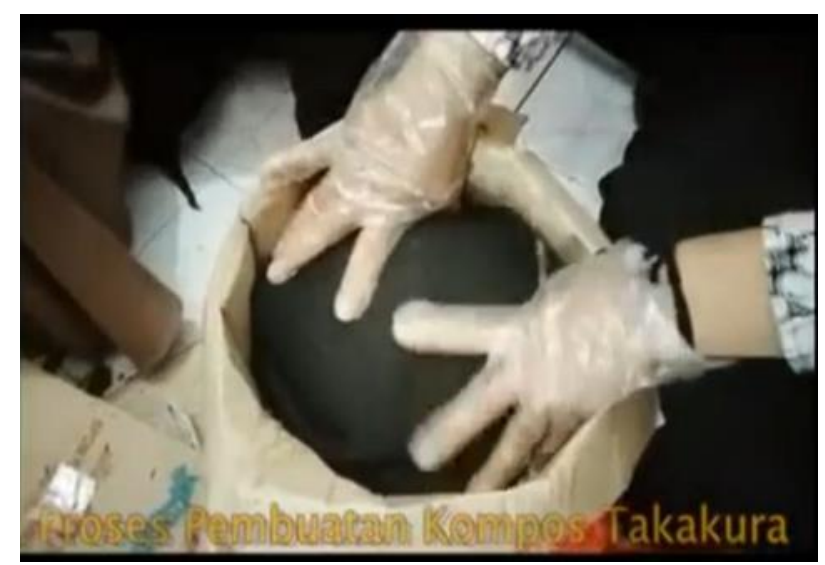

Gambar 3. Penutupan dengan bantal sekam

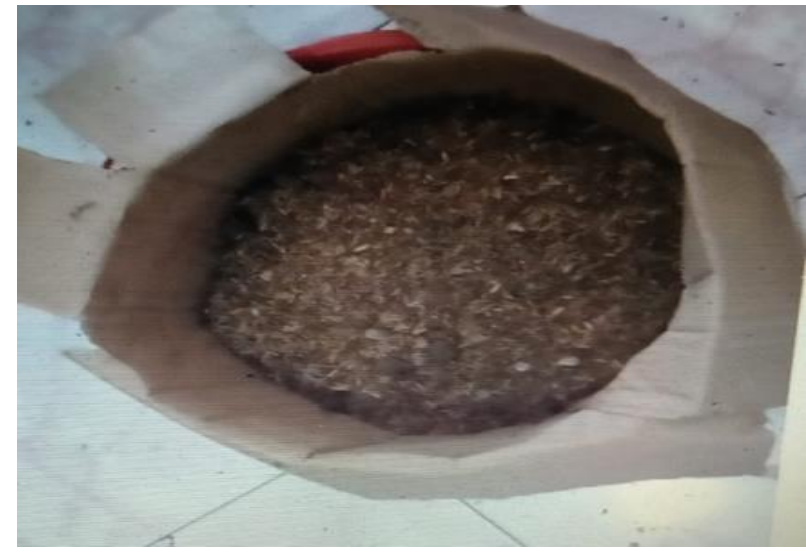

Gambar 5. Hasil kompos setelah 10 hari

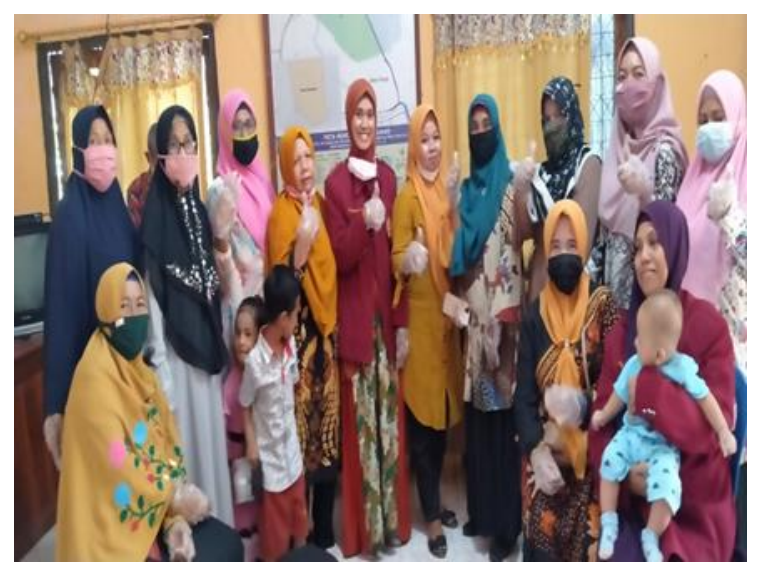

Gambar 4. Dokumentasi setelah kegiatan



Gambar 6. Ibu PKK telah memakai kompos

\section{d) Evaluasi}

Tim pengabdian melakukan evaluasi pertama program setelah 10 hari kegiatan pengabdian dilakukan yaitu pada taanggal 10 Agustus 2021 yang bertempat di Halaman Kantor Desa Waduwani. Keranjang Takakura yang berisi Kompos diletakkan di Halaman Samping kantor Desa. Tim Pengabdian yang didampingi beberapa staf desa dan Perwakilan ibu-ibu anggota PKK dari Desa waduwani, Keli dan Desa Naru. Para Ibu PKK dan Tim Pengabdian melihat hasil Kompos Takakura dan hasilnya sesuai dengan Harapan. Kompos dalam keadaan baik dan tidak berbau, selain itu kompos sudah siap dimanfaatkan oleh ibu-ibu untuk membantu menyuburkan tanaman ibu-ibu yang berada di rumah. Setelah itu Tim pengabdian membagikan kepada ibu-ibu hasil kompos dengan menggunakan plastic.Setelah itu Tim pengabdian akan melakukan evaluasi kedua untu melihat efek kompos terhadap tanaman warga.

Pada tanggal 20 Agustus 2021 Tim Pengabdian telah melakukan Evaluasi ke dua (2). Yaitu dengan agenda pertama melihat efek positif kompos terhadap tanaman bunga. Dan yang kedua yaitu bertujuan untuk menanyakan pada warga/ibu PKK apakah sudah membuat kompos dengan metode Takakura di rumah masing-masing. Hasil observasi dan evaluasi dari Tim Pengabdian yaitu ibu-ibu 
PKK telah menggunakan kompos dan hasilnya tanaman ibu-ibu PKK menjadi subur. Sedangkan berdasarkan wawancara Tim pengabdian, ibu PKK sebagian telah mempraktekkan membuat kompos di rumah. Sedangkan sebagian ibu PKK yang lain belum mempraktekkan karena beberapa alasan kesibukan.

\section{Kesimpulan}

\section{KESIMPULAN DAN SARAN}

Hasil dari pengabdian ini telah memenuhi tujuan pengabdian ini, yaitu (1) Adanya peningkatan pengetahuan dan keterampilan ibu-ibu dalam mengelola sampah, itu ditandai dengan ibu-ibu telah mengetahui urutan pembuatan sampah menjadi kompos, yaiyu pada saat kegiatan dan juga saat evaluasi ke 2 kegiatan, beberapa ibu-ibu telah mempraktekkan pembuatan sampah organic menjadi kompos di rumah mereka (2) adanya pengengurangan volume sampah yang dihasilkan pada skala Rumah tangga/sampah dapur. Itu ditandai dengan berkurangnya volume sampah yang ibu-ibu buang menjadi berkurang yang biasanya 2 kantung plastic menjadi 1 plastik saja, data ini berdasarkan hasil wawancar dan observasi tim pengabdian pada evaluasi ke dua. (3) Hasil pelatihan berupa kompos dimanfaatkan langsung oleh ibu-ibu untuk menyuburkan tanaman bunga dan sayur. Itu bisa terlihat pada saat Tim Pengabdian melakukan evaluasi pada tahap I dan II, ibu-Ibu PKK telah memanfaatkan kompos untuk menyuburkan tanaman sayur dan bunga. Ibu-ibu mengatakan tanaman mereka menjadi lebih subur dan sehat.

\section{Saran}

Pertama, Secara umumnya Masyarkat dan khususnya ibu-ibu perlu mendapat perhatian khusus dari pemerintah Desa, dalam merutinkan kegiatan pembuatan Kompos dari sampah organic dengan metode takakura minimal 2 kali dalam sebulan. Sehingga kegiatan pembuatan sampah menjadi kegiatan yang berkelanjutan. Hasilnya masyarakat dapat meminimalisir volume sampah yang ada di TPA waduwani, dan desa secara umumnya. Kedua, apabila ibu-ibu rutin membuat/mengolah sampah, kompos tersebut dapat dijual untuk menambah penghasilan

\section{Ucapan Terima Kasih}

Tim Pengabdian mengucapkan terima kasih kepada Sekolah Tinggi Ilmu Pendidikan dan Keguruan (STKIP) Taman Siswa Bima, khususnya Pak ketua Dr. Ibnu Khaldun Sudirman, M. Si. Terima kasih Kepada ketua LPPM, rekan dosen, dan Mitra pengabdian ini yaitu Pemerintah Desa dan masyarakat Desa Waduwani yang telah berpartisipasi aktif dalam mengikuti dan mensukseskan kegiatan pengabdian

\section{DAFTAR PUSTAKA}

Anonim. 2020. Metode Kompos Takakura, Cara Mudah Mengolah Limbah Rumah Tangga Menjadi Kompos. Diakses di https://www.banjarejo-tanjungsari.desa.id: https://www.banjarejotanjungsari.desa.id/first/artikel/1858-Metode-Kompos-Takakura--Cara-Mudah-Mengolah-

Limbah-Rumah-Tangga-Menjadi-Kompos. Diakses tgl Maret 15, 2021

Arsip Desa .2020. diambil tanggal 24 maret 2021, Pukul 09;00 WITA

Ilyas. 2021. Wawancara diambil tanggal 24 maret 2021, pukul 10:00 WITA

Imelda, dkk. (2020). Pelatihan Pengelolaan Sampah Rumah Tangga dengan Metode Komposting di Desa Kerinjing, Kabupaten Ogan Ilir. Sricommerce: Journal of Sriwijaya Community Services, 107-114.

Junaid, R. 2021. Wawancara diambil tanggal 24 maret 2021, pukul 10:00 WITA 
Rahmansyah. Wawancara diambil tanggal 25 maret 2021, pukul 11:00 WITA

Dewi Jumiarni, dkk .2020. Penerapan Teknologi Kompos Takakura Bagi Masyarakat Desa Tanjung Terdana Kecamatan Pondok Kubang Bengkulu Tengah Sebagai Upaya Pemberdayaan Masyarakat Sadar Lingkungan; Jurnal Ilmiah Pengembangan dan Penerapan IPTEKS. Vol 1, no 18. 